\title{
Shock Wave of a New Pandemic: Response of Antenatal Women in Ebonyi State, Nigeria to Corona Virus 19 Infection-Knowledge, Attitude and Practice
}

\author{
Chidi Esike1" ${ }^{*}$ Justus Eze1, Okechukwu Anozie1, Emeka Onwe'2, \\ Richard Ewah ${ }^{3}$, Esther Emeka-Irem1', Ndukwe Nwigboji1, \\ Emeka Ukaegbe ${ }^{1}$, Ugochukwu Nnadozie ${ }^{4}$, Odidika Umeora ${ }^{1}$
}

\begin{abstract}
${ }^{1}$ Department of Obstetrics and Gynecology, Alex Ekwueme Federal University Teaching Hopital, Abakaliki, Ebonyi State, Nigeria ${ }^{2}$ Department of Pediatrics, Alex Ekwueme Federal University Teaching Hopital, Abakaliki, Ebonyi State, Nigeria ${ }^{3}$ Department of Anesthesia, Alex Ekwueme Federal University Teaching Hopital, Abakaliki, Ebonyi State, Nigeria ${ }^{4}$ Division of Plastic Surgery, Department of Surgery, Alex Ekwueme Federal University Teaching Hopital, Abakaliki, Ebonyi State, Nigeria

Email: *drchidiesike@yahoo.com
\end{abstract}

How to cite this paper: Esike, C., Eze, J., Anozie, O., Onwe, E., Ewah, R., Emeka-Irem, E., Nwigboji, N., Ukaegbe, E., Nnadozie, U. and Umeora, O. (2021) Shock Wave of a New Pandemic: Response of Antenatal Women in Ebonyi State, Nigeria to Corona Virus 19 Infection-Knowledge, Attitude and Practice. Advances in Infectious Diseases, 11, 29-41. https://doi.org/10.4236/aid.2021.111005

Received: October 27, 2020

Accepted: March 7, 2021

Published: March 10, 2021

Copyright $\odot 2021$ by author(s) and Scientific Research Publishing Inc. This work is licensed under the Creative Commons Attribution International License (CC BY 4.0).

http://creativecommons.org/licenses/by/4.0/

\section{(c) (i) Open Access}

\begin{abstract}
Background: There are no known effective vaccines or drugs for curing the corona 19 virus infection as at present knowlede. This leaves the world with mainly controlling the source of infection and cutting off the transmission route through preventive measures to contain the pandemic. These entail active participation of people, high level of discipline and strict and meticulous adoption of preventive measures. Since it is known that knowledge, precautionary behavior and active social participation of the public are important to control the pandemic, this study sets out to evaluate these in the antenatal population in Ebonyi State. Objective: To evaluate the Knowledge, attitude and practice of the respondents to the corona virus 19 infection and its prevention. Methods: A self-administered pre-tested questionnaire was administered to pregnant women attending antenatal clinics in the chosen Mission hospitals and the only tertiary health institution that offer antenatal care to the bulk of antenatal population in the state. The results were analyzed using SPSS version 20 and Microsoft Excel 2016. Result: The participants had very good knowledge of corona virus 19 infection and its prevention but there were some gaps and misconceptions in knowledge and some of their attitudes and perceptions that raised concerns. Their practice of corona virus 19 preventive measures was poor despite their good knowledge. Conclusion: There
\end{abstract}


is need to fashion out programs and policies that will address the gaps and concerns unearthed in the study to enhance the protection of this vulnerable study population and the general public.

\section{Keywords}

Knowledge, Practice, Antenatal Population, Ebonyi, Nigeria

\section{Introduction}

The outbreak of the Corona virus 19 infection was a novel strain of the Corona virus in Wuhan China [1] in December 2019. From these earlier reported cases in China, it has spread to the countries of the world leaving in its wake grave devastations, morbidity and mortality in affected persons [2]. This virus with no known ethnic, racial or socio-cultural bias was declared an international public health emergency of international concern by the World Health Organization (WHO) in January 2020 [3] and a pandemic on $11^{\text {th }}$ March 2020 [4].

Despite its known continued aggressive devastation on all populations, there are no known effective vaccines or drugs for curing it as at the present level of knowledge [5]. This leaves the world with mainly controlling the source of infection and cutting off the transmission route through social distancing, hand washing and other preventive measures as the only source of containing the pandemic [6] for now. These entail active participation of people, high level of discipline and strict and meticulous adoption of preventive measures [7].

The commonest clinical features of COVID 19 include fever, cough, acute respiratory distress, difficulty in breathing etc. [8]. Pattern of spread and importation of the Corona virus 19 in Africa affirms previously published reports assessing preparedness and vulnerability of African countries to the virus and $\mathrm{Ni}$ geria has variable capacity and high vulnerability to the virus [9].

Despite spirited efforts by African countries including Nigeria to stop the virus from gaining entry into them, measures failed and on February 20, $2020 \mathrm{Ni}$ geria reported her first case of Corona Virus 19 infection in Lagos in an Italian National [10]. The virus has since then spread to all the states of Nigeria, Ebonyi State inclusive.

The antenatal population is not discriminated against by the virus in its spread and is understandably most likely to have higher vulnerability to the COVID 19 infection unlike other members of the population [11]. Also, the case of pregnant women is even more precarious and has more grave implications for the society as the infection of the virus may be both for the mother and her unborn baby especially with the implication of the transmission of the virus to the unborn baby not being fully elucidated.

Since prevention is key to avoiding being infected by the virus and it has been 
confirmed that the knowledge, perception and precautionary behaviors and active social participation of the public have been found to be important in the control of the pandemic, it is important to evaluate these indices in a population to further assess how they are coping in preventing the disease and what further measures that can be undertaken in fashioning policies that will keep the population safe. This, coupled with the fact that no study had been done to evaluate the knowledge, attitude, perception and practice of our antenatal population towards the corona virus 19 infection and practices towards its prevention in this population in Ebonyi State makes this study a necessity. The outcome will help identify gaps that can be filled by strengthening policies, addressing fears and concerns and improving implementation of preventive measures, not only in the antenatal but the general population toward the prevention of contraction of COVID 19 infection by these vulnerable population and their families.

\section{Methods}

Ebonyi State where this study was carried out, is one of the 36 states that make up Nigeria and it is located in the Southeast geo-political zone of the country. From 2006 National population Commission, the state has a population of $2,176,947$ people [12]. It has 3 senatorial zones. The health indices like most other states in the country are poor and the government's primary and secondary health systems are near collapse leaving five missionary hospitals namely Mile Four hospital Abakaliki, Mater Hospital Afikpo, St Vincent's Hospital Ndubia, Presbyterian Joint Hopital, Uburu, and Sudan Interior Mission Iziogo and Alex Ekwueme Federal University Teaching Hospital in Abakaliki in the state to cater for a significant number of the antenatal population of the state. The Teaching hospital was chosen for this study as the only tertiary hospital in the state out of the two hospitals in Abakaliki (Mile Four Hospital being the other one). By simple balloting, St Vincent's Hospital Ndubia was chosen of the two hospitals in Izzi Local Government Area and Mater hospital by simple balloting out of the two mission hospitals in Ebonyi South Senatorial zone.

A well-structured, self administered questionnaire which was pre-tested in one of the mission hospitals not chosen for the study (the Mile four Hospital, Abakaliki) and corrections made was administered on women who came for antenatal clinics in these hospitals from May to July 2020. The results were collated and analysed.

\section{Results}

Three hundred and ninety-six questionnaires were distributed but 385 or $97.2 \%$ were completely filled and analyzed using both descriptive and inferential statistics with the aid of Statistical Package for Social Sciences version 20 and Microsoft Excel 2016. 
The age range of participants as can be seen in Table 1 was 18 to 44 with a mean age of $27.9( \pm 5.4)$ years. Also as can be seen from table one, majority of the participants, 146 (37.9\%) were in the business/trading occupation, civil servants were in the second position with 101 (26.2\%). Majority, 380 (98.7\%) were Christians and 371 (96.4\%) were married. In terms of educational status (Table 1), majority, 180 (46.8\%) had tertiary education followed by 150 (39\%) who had secondary education while $27(7 \%)$ had primary level education and $8(2.1 \%)$ no education at all. Majority of participants, 203 (52.7\%) were in the Para 1 to 4 bracket (Table 1).

All our study participants, 385 (100\%) had heard of corona virus 19 (Table 3). From Table 2 and Figure 1, majority of our study participants, 344 (89.4\%) had good knowledge of the epidemiology of corona 19 virus and its infection while the knowledge was fair in 37 (9.6) and poor in $4(1 \%), 323(89.9 \%)$ had good knowledge of the clinical features and the knowledge in $22(5.7 \%)$ of them was poor. When the knowledge of prevention was analysed, majority, 302 (78.4\%) had good knowledge, 80 (20.4\%) fair and $3(0.8 \%)$ was poor.

Despite the overall good knowledge of our participants of COVID-19 virus and its infection, some disturbing gaps existed in the knowledge of some segments of the participants in some vital aspects (Table 3 ). Though majority of $323(84.2 \%)$ knew that Corona virus was caused by a virus $3(1.3 \%)$ thought it was caused by witchcraft and though majority, 361 (93.8\%) believe Corona virus 19 infection is real, 24 (6.2\%) did not think so.

While 326 (84.7\%) was right in thinking that Corona Virus 19 infection can infect anybody, 28 (7.3\%) thought it was a disease of rich people, $12(3.1 \%)$ said it was a disease of white people, 19 (14.9\%) thought it was due to witchcraft and 121 (31.4\%) thought that corona virus 19 infection was a death sentence (Table 3). While $182(47.3 \%)$ knew that persons infected by the corona virus could look healthy and normal, 145 people (37.7\%) did not know that while 58 (15.1\%) of the participants were not sure. Also, Table 3 shows that 18 (4.7\%) women did not think that the virus can infect pregnant women and 22 (5.7\%) were not sure.

From Table 4, majority of the respondents 210 (54.5\%) were afraid that they will not be responded to by hospitals if they had corona virus 19 infection. However, majority of $322(83.6 \%)$ will present to the hospital for treatment if they have the infection. While 326 (84.7\%) of the participants will not hide their COVID 19 status to avoid ridicule from others, 41 (10.6\%) will. Majority, 321 (83.4\%) thought that peoples' attitude will make an infected person feel bad and $205(63.6 \%)$ thought that the community will reject and stigmatize infected patients and relatives (Table 4).

Also as can be seen from Table 4, majority of participants 207 (53.8) will be afraid to stay with COVID 19 patient who had been certified cured. Majority of the participants, 176 (45.7\%) did not think they had enough information on COVID 19 virus infection while 318 (82.6\%) thought they needed more information to understand COVID 19 virus infection better. 
Table 1. Socio-demographic data of respondents.

\begin{tabular}{|c|c|c|}
\hline Variable & Frequency & Percentage (\%) \\
\hline \multicolumn{3}{|l|}{ Age } \\
\hline $16-20$ & 18 & 4.7 \\
\hline $21-25$ & 129 & 33.5 \\
\hline $26-30$ & 137 & 35.6 \\
\hline $31-35$ & 65 & 16.9 \\
\hline $36-40$ & 30 & 7.8 \\
\hline $41-45$ & 6 & 1.6 \\
\hline Mean (Std dev) & $27.99(5.338)$ & \\
\hline Age range & $18-44$ & \\
\hline \multicolumn{3}{|l|}{ Occupation } \\
\hline Business/Trading & 146 & 37.9 \\
\hline Farmer & 22 & 5.7 \\
\hline Civil Servant & 101 & 26.2 \\
\hline Vocational & 25 & 6.5 \\
\hline Applicant & 28 & 7.3 \\
\hline House Wife & 18 & 4.7 \\
\hline Student & 45 & 11.7 \\
\hline \multicolumn{3}{|l|}{ Religion } \\
\hline Traditional & 3 & 0.8 \\
\hline Christian & 380 & 98.7 \\
\hline Islam & 0 & 0 \\
\hline Others & 2 & 0.5 \\
\hline \multicolumn{3}{|l|}{ Address } \\
\hline Urban & 160 & 41.6 \\
\hline Rural & 225 & 58.4 \\
\hline \multicolumn{3}{|l|}{ Marital Status } \\
\hline Married & 371 & 96.4 \\
\hline Single & 13 & 3.4 \\
\hline Separated & 0 & 0 \\
\hline Widow & 1 & 0.3 \\
\hline \multicolumn{3}{|l|}{ Education } \\
\hline None & 8 & 2.1 \\
\hline Primary & 27 & 7.0 \\
\hline Secondary & 150 & 39.0 \\
\hline Tertiary & 180 & 46.8 \\
\hline Post tertiary & 20 & 5.2 \\
\hline \multicolumn{3}{|l|}{ Parity } \\
\hline 0 & 133 & 34.5 \\
\hline $1-4$ & 203 & 52.7 \\
\hline$\geq 5$ & 49 & 12.7 \\
\hline
\end{tabular}


Table 2. Knowledge of different components of the corona virus 19 infection.

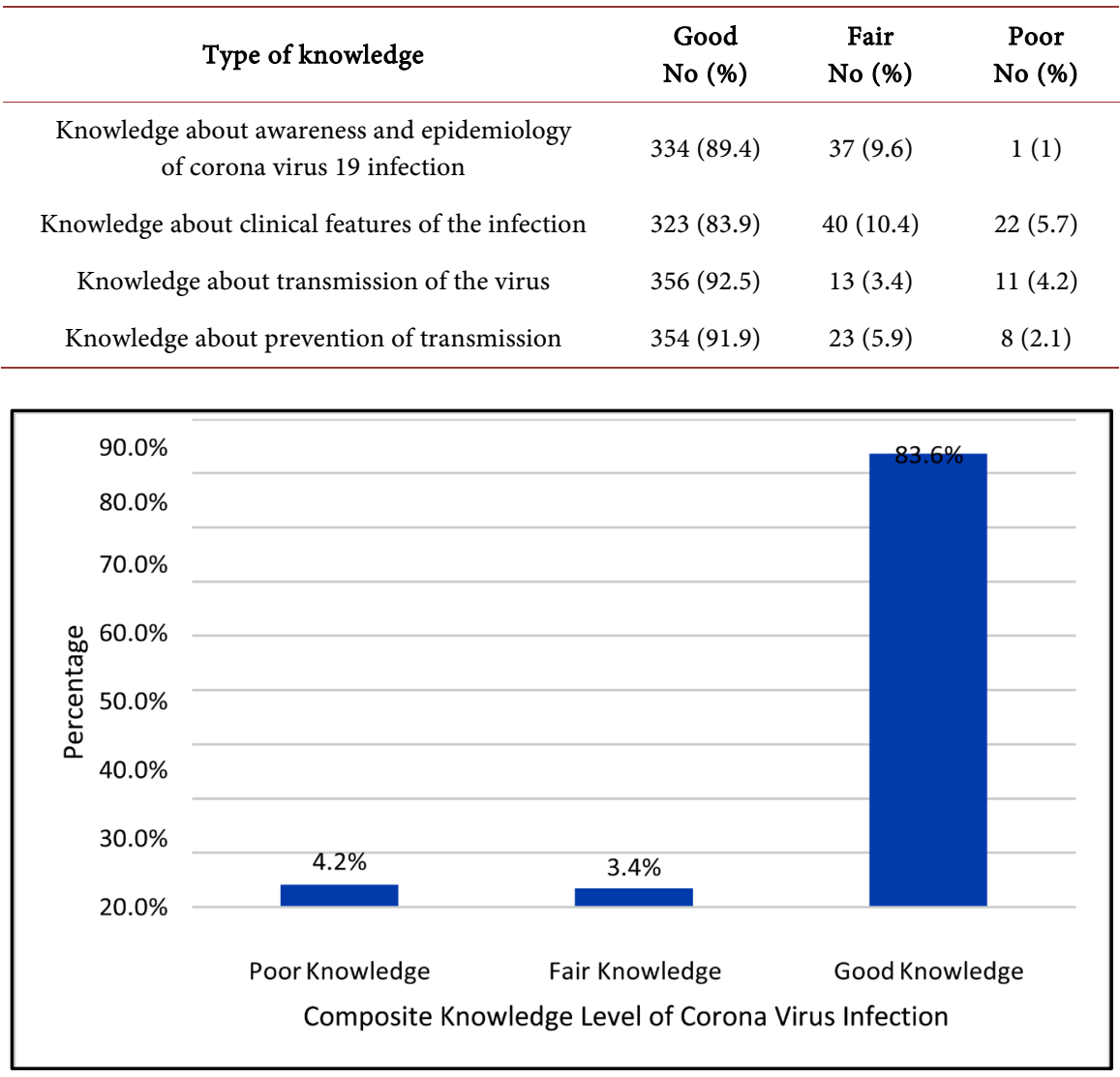

Figure 1. Composite knowledge level of corona virus among respondents.

Table 3. Awareness and knowledge of epidemiology of corona virus infection among respondents.

\begin{tabular}{ccc}
\hline Variable & Frequency & Percentage (\%) \\
\hline Heard of corona virus before & 385 & 100 \\
Yes & 0 & 0 \\
No & & \\
Origin of corona virus & 22 & 5.7 \\
America & 3 & 0.8 \\
Italy & 352 & 91.4 \\
China & 8 & 2.1 \\
United Kingdom & & \\
Cause of corona virus & 28 & 7.3 \\
Rat & 6 & 1.6 \\
Mosquitoes & 22 & 5.7 \\
A germ called bacteria & 324 & 1.3 \\
A germ called virus & 5 & \\
Witchcraft & &
\end{tabular}




\section{Continued}

Believe that corona virus infection is real

$\begin{array}{lcc}\text { Yes } & 361 & 93.8 \\ \text { No } & 24 & 6.2\end{array}$

Group of people affected by corona virus infection

$\begin{array}{ccc}\text { Rich people } & 28 & 7.3 \\ \text { White people } & 12 & 3.1 \\ \text { Chinese } & 19 & 4.9 \\ \text { Anybody } & 326 & 84.7\end{array}$

Is corona virus infection a death sentence?

$\begin{array}{ccc}\text { Yes } & 121 & 31.4 \\ \text { No } & 217 & 56.4 \\ \text { Not Sure } & 47 & 12.2\end{array}$

Can corona virus affect pregnant women?

$\begin{array}{ccc}\text { Yes } & 345 & 89.6 \\ \text { No } & 18 & 4.7 \\ \text { Not Sure } & 22 & 5.7\end{array}$

Can an infected person look healthy and normal

$\begin{array}{ccc}\text { Yes } & 182 & 47.3 \\ \text { No } & 145 & 37.7 \\ \text { Not Sure } & 58 & 15.1\end{array}$

Table 4. Attitude of respondents towards corona virus infection.

\begin{tabular}{ccc}
\hline Variable & Frequency & Percentage (\%) \\
\hline Afraid that hospitals will not attend to you & 134 & 34.8 \\
No & 210 & 54.5 \\
Not Sure & 41 & 10.6 \\
Hide viral status to avoid ridicule from others & & \\
Yes & 41 & 10.6 \\
No & 326 & 84.7 \\
Not Sure & 18 & 4.7 \\
Yes & & 11.9 \\
No & 46 & 83.9 \\
Not Sure & 323 & 4.2 \\
Yresent yourself to hospital for treatment & 16 & 83.6 \\
\hline
\end{tabular}


Continued

$\begin{array}{ccc}\text { No } & 43 & 11.2 \\ \text { Not Sure } & 20 & 5.2\end{array}$

Afraid to stay with a certified cured/discharged COVID 19 patient

$\begin{array}{ccc}\text { Yes } & 207 & 53.8 \\ \text { No } & 178 & 46.2 \\ \text { Not Sure } & 0 & 0\end{array}$

Think that people's attitude will make an infected person feel bad

$\begin{array}{ccc}\text { Yes } & 321 & 83.4 \\ \text { No } & 48 & 12.5 \\ \text { Not Sure } & 16 & 4.2\end{array}$

Think community will reject and stigmatize infected patients and relatives

$\begin{array}{ccc}\text { Yes } & 245 & 63.6 \\ \text { No } & 98 & 25.5 \\ \text { Not Sure } & 42 & 10.9\end{array}$

Think you have enough information on corona virus infection

$\begin{array}{ccc}\text { Yes } & 162 & 42.1 \\ \text { No } & 176 & 45.7 \\ \text { Not Sure } & 47 & 12.2\end{array}$

Think you need more information to understand better

\begin{tabular}{ccc} 
Yes & 318 & 82.6 \\
No & 67 & 17.4 \\
Not Sure & 0 & 0 \\
\hline
\end{tabular}

When it comes to practicing the protective measures that will help participants to prevent the corona virus 19 infection, it was found (Table 5) that though majority of them, 370 (96.1\%) had face masks, only 188(48.8\%) of them use the face mask every time they were outside their houses and of this number, only 93 (24.2\%) wore their face masks properly to cover their mouths and noses. Others $292(75.8 \%)$ put their face masks in their bags or wore them on their jaws. Only 138 (35.8\%) of participants coughed into tissue papers or their bent elbows, 165 or $42.9 \%$ maintained a social distance of at least one meter and only 183 or $47.5 \%$ of participants washed their hands regularly with soap and water or used hand sanitizer. Many of participants 176 (45.7\%) did not think they had enough information about the infection and majority, 318 (82.6\%) thought they needed more information.

\section{Discussion}

Our study population had an age range of 18 to 44 years with a mean population age of $27+$ or -5.4 years. One hundred and eighty or (46.82\%) had tertiary and $150(39 \%)$ secondary levels of education. These show generally that they were 
Table 5. Preventive measures of corona virus infection among respondents.

\begin{tabular}{|c|c|c|}
\hline Variable & Frequency & Percentage (\%) \\
\hline \multicolumn{3}{|c|}{ Have a face mask } \\
\hline Yes & 370 & 96.1 \\
\hline No & 12 & 3.1 \\
\hline Not Sure & 3 & 0.8 \\
\hline \multicolumn{3}{|c|}{ Frequency of facemask use outside the house } \\
\hline At times & 82 & 21.3 \\
\hline Often & 115 & 29.9 \\
\hline All the time & 188 & 48.8 \\
\hline \multicolumn{3}{|c|}{ Cover my mouth and nose with facemask whenever I'm outside the house } \\
\hline At times & 54 & 14.0 \\
\hline Occasionally & 80 & 20.8 \\
\hline All the time & 251 & 65.2 \\
\hline \multicolumn{3}{|c|}{ Put facemask in bag or below the jaw whenever I'm outside the house } \\
\hline Rarely & 64 & 16.6 \\
\hline Occasionally & 145 & 37.7 \\
\hline Often times & 83 & 21.6 \\
\hline Never & 93 & 24.2 \\
\hline
\end{tabular}

fairly well educated and knowledgeable. Knowledge about corona virus 19 in our study population was very high with 344 (89.4\%) having good knowledge of the awareness and epidemiology of the infection, 323 (89.9\%) of the clinical features and 356 (92.5\%) of transmission of the infection. This good knowledge of the various aspects of the disease in our study could be attributable to the high level of education of our participants as majority of $180(64.8 \%)$ had tertiary level of education followed by 150 (39\%) with secondary education. Education had always been associated with better knowledge of diseases by the public including epidemics, pandemics, etc. [12].

These findings are in keeping with other studies which found education to be highly associated with good knowledge of COVID 19 pandemic [13] [14] [15]. This similarity could be due to the fact that their participants also had high level of education like ours. Estani et al. in their study in Iran also found that lower levels of education were associated with lower levels of knowledge about COVID 19 virus infection [10] [16]. Equally an important contribution to their good knowledge is the fact that correct and accurate information about the virus was passed to them directly during health talks by health workers during their antenatal clinics. Also important is the huge publicity mounted by both governmental and non-governmental organizations through the various media of communication about the virus.

Despite this overall good knowledge of different aspects of COVID 19 virus 
infection in our antenatal population, disturbing gaps existed on some salient aspects of knowledge of the disease in small percentage of the study population. Though these people were not in the majority, there is need to design measures to properly educate this sub population on the correct facts regarding the infection. For instance, irrespective of the fact that majority of our study population knew the correct cause of COVID 19 infection as a virus, others, 24 (6.2\%) did not think corona virus was real and 28 (7.3\%) thought it was a disease of white people, $19(4.9 \%)$ a disease of Chinese people and 121 (31.42\%) thought that corona virus infection was a death sentence. These are disturbing misconceptions because these participants will not do enough to protect themselves and family from the harmful effects of the virus thus exposing a huge number of people to the highly contagious virus. Also as mothers, they will not be convinced about the true nature of virus and will pass on wrong and dangerous misconceptions to their family and friends.

These misconceptions though not in the majority, are significant enough for programmes to be designed and modified to educate this population more correctly and disabuse their minds from these misconceptions. This is very important because these are pregnant mothers who if they get this disease due to their lack of correct knowledge will jeopardize their babies and the health workers who will be attending to them. They should therefore be made to transmit correct information to their families. Moreover, the correct education and information to their families depend on these women who if they are not correctly informed cannot educate their children and other family members correctly. Also, these women will be taken to have the best knowledge about the virus being consistently taught about it in antenatal clinics by health workers. The wrong knowledge will definitely be worse in the general population.

Like in the study from Iran [15], high exposure of the Nigerian population to intense government and nongovernmental media information even before the outbreak of the virus in Nigeria and heightened since the index case in February 2020 in Lagos had been contributory to the high level of knowledge and the high knowledge base of our study participants The high level of knowledge in our study participants hoewever, contrasts with the study in Thailand in the early period of the pandemic where the majority of their residents had poor knowledge of the pandemic [11] [17]. This could be attributed to the fact that their work was carried out in the general population who generally may most likely have lower education level and also due to the fact that the study was carried out at a time that the COVID 19 virus infection had not been firmly established in their country. With regard to the attitude of our participants to the corona 19 virus infection, majority, $322(83.6 \%)$ will present to the hospital if they have corona virus 19 infection. However, although majority of them will present to the hospital for treatment if they have the infection, majority of them 210 (54.5\%) were afraid that they will not be responded to by hospitals if they had the infection. This is a fear that must be addressed by policy makers and health 
workers in other not to worsen the adverse impact of the infection.

While $326(84.7 \%)$ of the participants will not hide their COVID 19 status to avoid ridicule from others, $41(10.6 \%)$ will. Majority, $321(83.4 \%)$ think that peoples' attitude will make an infected person feel bad and $205(63.6 \%)$ think that the community will reject and stigmatize infected patients and their relatives.

Majority of participants 207 (53.8) will be afraid to stay with COVID 19 patients who had been certified cured.

The attitude of majority of our participants not hiding their status and willing to present to the hospital if infected with the virus is good. However, the fear that health workers will not attend to them and other concerns raised by this study are genuine concerns. Programmes must be designed to beef up the knowledge and confidence of health workers about the disease and to train and retrain them to carry out their functions both in professionally protecting themselves and giving the best available treatment to their patients without discrimination.

Majority, 321 (83.4\%) of our participants thought that peoples' attitude will stigmatize COVID 19 infected persons and make them feel bad and 245 (63.6\%) thought that the community would. This is bad and should also be addressed. Stigma towards COVID 19 is due to the fear of its mortality and high communicability, thus can be resolved through proper education and transparency of healthcare policies [18].

When we investigated the implementation of those practices that would help them prevent the contraction of corona virus infections, it was found that their practices of these preventive measures were poor despite their good knowledge of those practices. For instance, though majority of them, 370 (96.1\%) had face masks, only 188 (48.8\%) of them used the face mask every time they were outside their houses. And of this number, only 93 (24.2\%) wore their face masks properly to cover their mouths and noses. Others 292 (75.8\%) put their face masks in their bags or wore them on their jaws. This practice of not putting on face masks properly all the time is not good and will enhance the transmission of the infection. This is in contradistinction to a Chinese study where almost all the participants were wearing face masks [13].

This is a questionnaire based cross-sectional study and has the weaknesses associated with this type of study. Also despite the fact that all efforts were made to encourage the participants to answer the questions as truthfully as possible, there was the possibility that a few could have given answers they thought would impress their caregivers.

From this study, it was found out that the antenatal women in Ebonyi State of Nigeria have very good knowledge of all the aspects of the corona virus 19 infection but despite this good knowledge disturbing gaps, wrong information and misinformation that will require correcting still exist. Also, their attitude exposes some concerns and fear of stigmatization by the society and rejection of infected people by the hospitals. Their practices of the preventive measures that will protect them against this infection were poor. They also thought that they 
needed more information about the virus. Programs should be designed by policy makers and relevant agencies to address these gaps and fears in other to curtail the spread and mitigate the damages caused by this pandemic especially in Nigeria.

\section{Conflicts of Interest}

The authors declare no conflicts of interest regarding the publication of this paper.

\section{References}

[1] Lu, R., Zhao, X., Li, J., Niu, P., Yang, B., Wu, H., et al. (2020) Genomic Characterization and Epidemiology of 2019 Novel Coronavirus Implication for Virus: Implication for Virus Origins and Receptor Binding. The Lancet, 395, 565-674. https://doi.org/10.1016/S0140-6736(20)30251-8

[2] Munster, V.J., Kopmans, M., Van Doremalen, N., Van Riel, D. and de Wit, E. (2020) A Novel Coronavirus Emerging in China-Key Questions for Impact Assessment. The New England Journal of Medicine, 382, 692-694.

[3] WHO Statement on the Second Meeting of the International Health Regulation (2005) Emergency Committee Regulating the Outbreak of the Novel Corona Virus (2019-n COV).

https://www.who.int/news/item/30-01-2020-statement-on-the-second-meeting-of-t he-international-health-regulations-(2005)-emergency-committee-regarding-the-ou tbreak-of-novel-coronavirus-(2019-ncov)

[4] Baloch, S., Baloch, A.M., Zheng, T. and Pei, X. (2020) The Coronavirus Disease 2019 (COVID-19) Pandemic. The Tohoku Journal of Experimental Medicine, 250, 271-278. https://doi.org/10.1620/tjem.250.271

[5] Salin, A.R., Erdogan, A., Agaoglu, P.M., Dineri, Y., Cakirci, A.Y., Senel, M.E., et al. (2020) 2019 Novel Coronavirus (COVIDs 19) Outbreak: A Review of the Current Literature. EMJO, 4, 1-7.

[6] World Health Organization (2020) Coronavirus Disease 2019 (COVID 19) Situation Report-90. WHO, Geneva.

https://www.who.int/docs/default-source/coronaviruse/situation-reports/20200419sitrep-90-covid-19.pdf?sfvrsn=551d47fd 4

[7] World Health Organization (WHO) (2019) Coronavirus Disease (COVID 19) Advice for the Public.

https://www.who.int/emergencies/diseases/novel-coronavirus-2019/advice-for-publ ic

[8] Lake, M.A. (2020) What We Know So Far: COVID 19 Current Clinical Knowledge and Research. Clinical Medicine, 20, 124-127. https://doi.org/10.7861/clinmed.2019-coron

[9] Gilbert, M., Pullano, G., Pinnotti, F., Valdano, E., Poletto, C., Boelle, P.Y., et al. (2020) Preparedness and Vulnerability of African Countries against the Importation of COVID 19: A Modeling Study. The Lancet, 395, 871-877. https://doi.org/10.1016/S0140-6736(20)30411-6

[10] Reuben, C.R., Danladi, M.M.A., Saleh, D.A. and Ejembi, P.E. (2020) Knowledge, Attitudes and Practices towards COVID 19. An Epidemiological Survey in North Central Nigeria. Journal of Community Health. 
https://doi.org/10.1007/s10900-020-00881-1

[11] Zhao, X., Jiang, Y., Zhao, Y., et al. (2020) Analysis of the Susceptibility to COVID-19 in Pregnancy and Recommendations on Potential Drug Screening. European Journal of Clinical Microbiology \& Infectious Diseases, 39, 1209-1220. https://doi.org/10.1007/s10096-020-03897-6

[12] Federal Republic of Nigeria Official Gazette No 24 (2007) Lagos, 94, 13-184.

[13] Ziong, B.L., Luo, W., Li, H.M., Zang, Q.Q., Liu, X.G., Li, W.T. and Li, Y. (2020) Knowledge, Attitudes and Practices towards COVID 19 among Chinese Residents during the Rapid Rise Period of the COVID 19 Outbreak, a Quick Online Cross-Sectional Survey. International Journal of Biological Sciences, 19, 1745.

https://doi.org/10.7150/ijbs.45221

[14] Hafeez, F., Akram, W., Suhail, A. and Arshad, M. (2012) Knowledge and Attitude of the Public towards Dengue Control in Urban and Rural Areas of Punjab. Pakistan Journal of Zoology, 44, 15-21.

[15] Rahman, A. and Sathi, N.J. (2020) Knowledge, Attitude and Preventive Practices towards COVID 19 among Bangladesh Internet Users. Electronic Journal of General Medicine, 17, Em245. https://doi.org/10.29333/ejgm/8223

[16] Erfani, A., Shahriariad, R., Ranjbark, Miraamadizadeh, A. and Moghadami, M. (2020) Knowledge, Attitude and Practice towards the Novel Coronavirus (COVID 19) Outbreak. A Population-Based Survey in Iran. Bulletin of the World Health Organization.

[17] Srichan, P., Apidechkul, T., Tamorn park, R., Yeemard, F., Khunthasons, Kitchanapaijboon, S., et al. (2020) Knowledge, Attitude and Preparedness to Respond to the 2019 Novel Coronavirus (COVID 19) among the Bordered Population of Northern Thailand in the Earning Period of the Outbreak: A Cross Sectional Study. The Lancet. https://doi.org/10.2139/ssrn.3546046

[18] Abdelhafiz, A.S., Mohammed, Z., Ibrahim, E., Ziady, H.I., Alorabi, M., Ayyad, M., et al. (2020) Knowledge, Perceptions and Attitude of Egyptians towards the Novel Coronavirus Disease (COVID 19). Journal of Community Health, 45, 881-890. https://doi.org/10.1007/s10900-020-00827-7 